\title{
Evaluation of Hydrophilized Graphite Felt for Electrochemical Heavy Metals Detection $\left(\mathbf{P b}^{2+}, \mathbf{H g}^{2+}\right)$
}

\author{
Laila Bouabdalaoui, ${ }^{1,2,3}$ Benjamin Le Ouay, ${ }^{1,2,3}$ \\ Thibaud Coradin, ${ }^{1,2,3}$ and Christel Laberty-Robert ${ }^{1,2,3}$ \\ ${ }^{1}$ Sorbonne Universités, UPMC Universités Paris 06, UMR 7574, Chimie de la Matière Condensée de Paris, 75005 Paris, France \\ ${ }^{2}$ CNRS, UMR 7574, Chimie de la Matière Condensée de Paris, 75005 Paris, France \\ ${ }^{3}$ Collège de France, UMR 7574, Chimie de la Matière Condensée de Paris, 75005 Paris, France
}

Correspondence should be addressed to Christel Laberty-Robert; christel.laberty@upmc.fr

Received 5 May 2015; Revised 13 June 2015; Accepted 17 June 2015

Academic Editor: Shengshui Hu

Copyright (C) 2015 Laila Bouabdalaoui et al. This is an open access article distributed under the Creative Commons Attribution License, which permits unrestricted use, distribution, and reproduction in any medium, provided the original work is properly cited.

\begin{abstract}
Hydrophilized graphite felt has been used, for the first time, for the electrochemical detection of $\mathrm{Hg}^{2+}$ ions both as single metal species and via its simultaneous detection with $\mathrm{Pb}^{2+}$. To do so, square wave voltammetry (SWV) method was developed with alginate modified graphite felt as working electrode. The structure of the graphite felt such as its high porosity and specific surface area coupled with its good electrical conductivity allows achieving large peak currents via the SWV method, suggesting that the alginate coating helps to preconcentrate metals at the carbon surface. The as-described electrode has low cost, it is easy to manipulate, and the electrochemical analysis can be performed by simple immersion of the felt in the metal solution.
\end{abstract}

\section{Introduction}

Increasing of industrial activities in the world leads to the fast and important dissemination of heavy metals, such as lead, cadmium, and mercury, in grounds, in aqueous environments, and even in human beings. Unfortunately, heavy metals are not biodegradable and can exist in highly stable inorganic forms. In EU, drinking water standards correspond to metal concentrations between $1 \mu \mathrm{g} \mathrm{L}^{-1}\left(1 \times 10^{-8} \mathrm{M}\right)$ for mercury and $50 \mu \mathrm{g} \mathrm{L}^{-1}\left(2 \times 10^{-6} \mathrm{M}\right)$ for chromium. Therefore, many analytical techniques have been developed for detection of trace amounts of toxic heavy metals. Atomic spectrometric methods can reach low limits of detection but they are expensive and are unsuitable for easy on-field analysis [1-3]. On the opposite, electrochemical techniques, such as square wave voltammetry, are of low cost and easily operational and have excellent sensitivity and suitability for determination of multiple analytes [4-7]. However their performances are highly dependent on the choice of the electrode materials.
In this context, carbon-based materials have been shown to be ideal for a lot of electrochemistry-related applications such as hydrogen storage [8], solar cells [9], electrical batteries [10], and microbial fuel cells [11-13]. They usually combine a low cost, a high surface area, an excellent electrical conductivity, and significant electrocatalytic activity. Therefore carbon-based materials such as graphene, carbon nanotubes, and graphite nanofibers have already shown excellent performance in heavy metal detection [14]. To achieve low detection limit and better sensitivity, the grafting of organic molecules by chemical or electrochemical methods on the carbon surface has been achieved [15-17]. In particular, the introduction of functional groups that have strong affinity for metal species allows their preconcentrations on the electrode surface leading to lower detection limits with shorter accumulation times [14].

Of particular interest are graphite felts whose threedimensional (3D) structure consists of carbon fibers of around $10 \mu \mathrm{m}$ in diameter exhibiting a high surface area, a large porous volume (>90\%), and good conductivity [18]. 
They are therefore ideal candidates as electrodes in flow electrochemical sensors for trace metals analysis, as already shown for lead, zinc, and copper [18-22]. Using linear sweep stripping voltammetry (LSSV), limit of detection of lead as low as $10^{-9} \mathrm{M}$ was achieved using unmodified graphite felt [19] and $2.5 \times 10^{-8} \mathrm{M}$ using graphite felts modified by covalent attachment of 1,4,8-tri(carbamoylmethyl) hydroiodide (TETRAM) ligands [20] and cyclam ligands [21].

This work aimed at evaluating recently described hydrophilized graphite felt as a sensor for lead and at extending the applicability of such materials to mercury and cadmium detection. To favor water penetration, the surface of carbon was first coated with hydrophilic polymer, alginic acid [23, 24]. The electrochemical behavior of these electrodes was first studied by voltammetric measurements using potassium ferricyanide and ruthenium (III) hexammine chloride redox probes. Note that the electrochemistry behavior of unmodified electrode is poor. Low current density is measured due to the problem of accessibility of redox probes to the carbon surface. The modified graphite felt was then successfully applied to the individual and simultaneous determination of lead (II) and mercury (II) ions by square wave voltammetry. In contrast, the detection of cadmium (II) ions could not be achieved in a reliable manner. Our results suggest that, in addition to its hydrophilization effect, alginic acid can also contribute to the electrode performance by favoring the binding of metal ions on the carbon surface. Compared to work in the literature $[25,26]$ that used more sophisticated materials including graphene and nafion, we demonstrated the potentialities of these cheap, simple, and easily handled electrodes as environmental sensors.

\section{Material and Methods}

The raw graphite felt used in this study $(99.9 \%, 1 \mathrm{~cm}$ thick, Morgan Carbon, Luxemburg) consists of loosely assembled carbon fibers, $12 \mu \mathrm{m}$ in diameter, defining an open framework with cavities of ca. $100 \mu \mathrm{m}$. Its conductivity is ca. $0.04 \mathrm{~S} \mathrm{~cm}^{-1}$. To favor water penetration, the fibers surface was coated with alginic acid, following a methodology described by Le Ouay et al. $[23,24]$ and observed by scanning electron microscopy (SEM) (Hitachi S-3400N working at $10 \mathrm{kV}$ ). To do so, the graphite felt is first dipped in ethanol to eliminate air bubbles and then in a mixture of glycerol and water (75/25 in weight $\%$ ) for $1 \mathrm{~h} 30 \mathrm{~min}$. After this step, the graphite felt is immersed in solution containing $1 \%$ in weight of sodium alginate for $1 \mathrm{~h}$ 30 min under constant stirring. For prior electrochemistry experiments, the felt is rinsed in deionized water and dried at $90^{\circ} \mathrm{C}$ for 24 hours.

The electrochemical measurements were carried out with a VSP Bio-Logic potentiostat using a three-electrode cell. The reference electrode was $\mathrm{Ag} / \mathrm{AgCl} / \mathrm{KCl}_{\text {(sat) }}(0.197 \mathrm{~V} / \mathrm{NHE})$, the counter electrode was a Pt wire, and the working electrode was the graphite felt $\left(1 \mathrm{~cm}^{3}\right)$. Pt wire was fixed to the carbon felt and used as connector. The electrochemical behavior of the graphite felt was first studied by cyclic voltammetry $(\mathrm{CV})$ in the presence of $10^{-4} \mathrm{M}$ of potassium ferricyanide $\left(\mathrm{K}_{3}\left[\mathrm{Fe}(\mathrm{CN})_{6}\right]\right)$ and ruthenium (III) hexamine

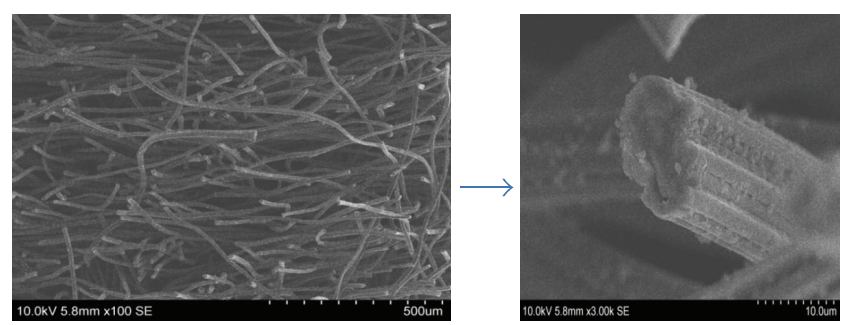

(a)

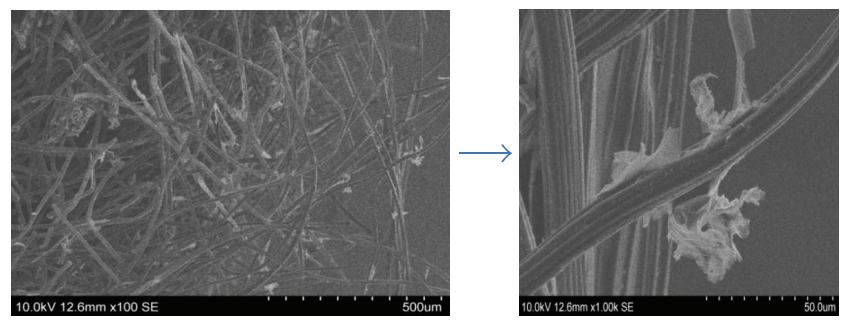

(b)

FIGURE 1: SEM of (a) raw graphite felt and (b) alginate-coated felt.

chloride $\left(\left[\mathrm{Ru}\left(\mathrm{NH}_{3}\right)_{6}\right] \mathrm{Cl}_{3}\right)$ as redox probes with a $0.129 \mathrm{M} \mathrm{KCl}$ solution ( $\mathrm{pH} 6$ ) as the supporting electrolyte.

For heavy metal detection experiments, stock solutions of $\mathrm{Pb}^{2+}, \mathrm{Hg}^{2+}$, and $\mathrm{Cd}^{2+}$ were prepared by diluting the corresponding standard solutions $\left(\mathrm{g} \mathrm{L}^{-1}\right)$ prepared with $\mathrm{Pb}\left(\mathrm{NO}_{3}\right)_{2}, \mathrm{Hg}$ metal, and $\mathrm{Cd}$ metal, respectively, in $2 \%$ nitric acid. A $0.1 \mathrm{M}$ sodium acetate/acetic acid buffer at $\mathrm{pH} 4.5$ was used as the supporting electrolyte. The square wave voltammetry (SWV) curves were recorded using the following optimized parameters: pulse height of $8 \mathrm{mV}$, pulse amplitude of $50 \mathrm{mV}$, and frequency of $12.5 \mathrm{~Hz}$. All solutions used for SWV measurements were deoxygenated with argon at least $15 \mathrm{~min}$ to remove oxygen prior to analysis. All measurements were performed under magnetic stirring. Prior to the square wave voltammetry, the graphite felt is kept at the open circuit for $15 \mathrm{~min}$. This operation induced preconcentration of ions at the surface of the graphite felt. We deliberately decide to report the current as function of the concentration as it was difficult to define a parameter for normalization. All experiments were carried out at room temperature.

\section{Results and Discussion}

SEM images of the graphite felt as such or after alginate coating are shown in Figure 1. The biopolymer appears to form large aggregates between the carbon fibers. Indeed these images are obtained after drying of the felt so it is difficult to infer alginate organization in the wet state. Nevertheless, it is important to point out that the alginate coating does not exert a significant influence on the porous structure of the felt. Accordingly, surface modification did not impact the conduction properties of the carbon network [23].

The electrochemical behavior of the modified graphite felt was first studied using two redox probes. Note that the electrochemical behavior of nonmodified graphite felt has not 


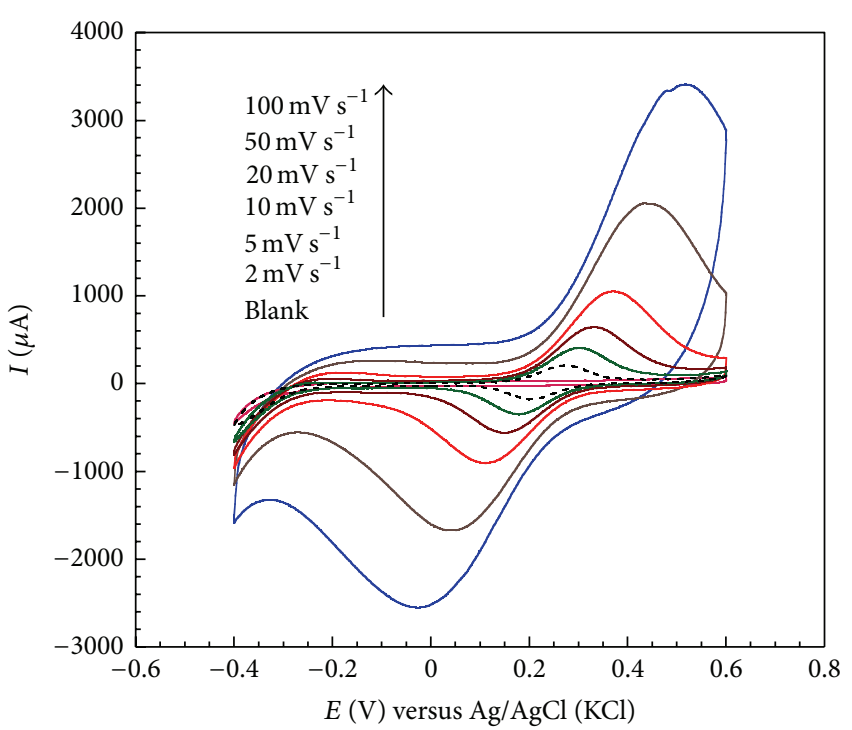

(a)

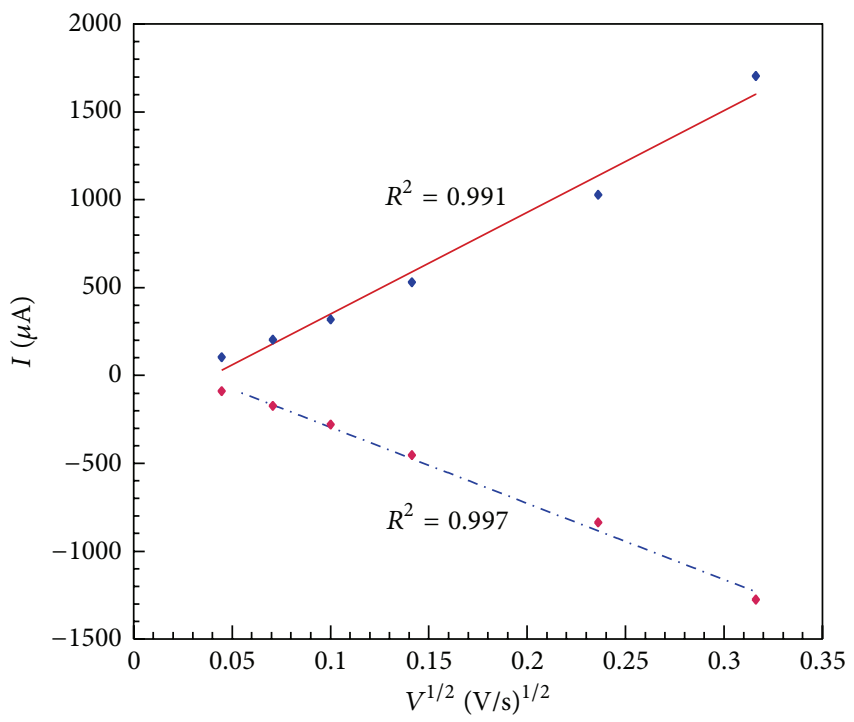

(c)

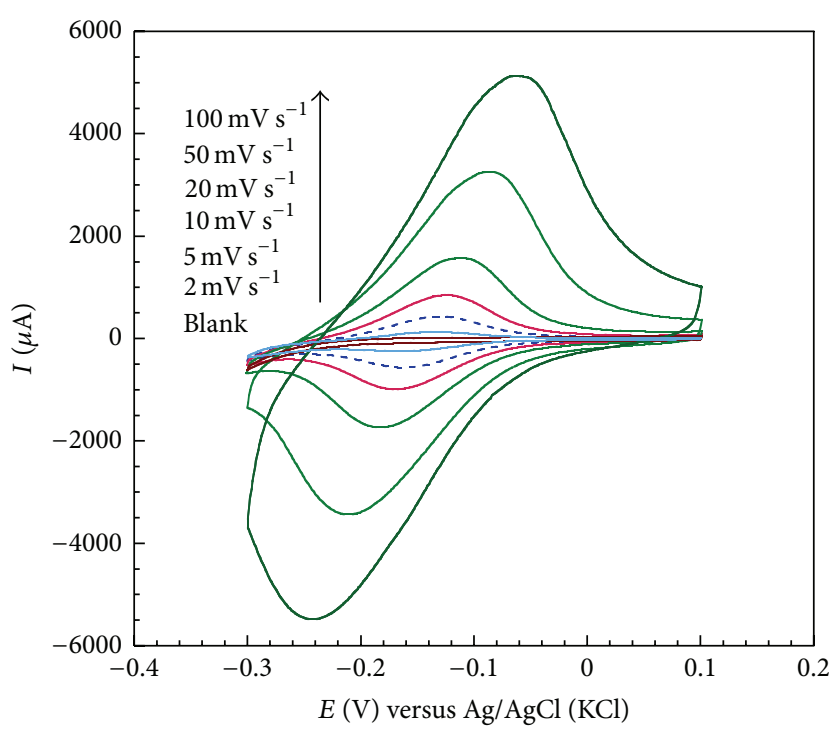

(b)

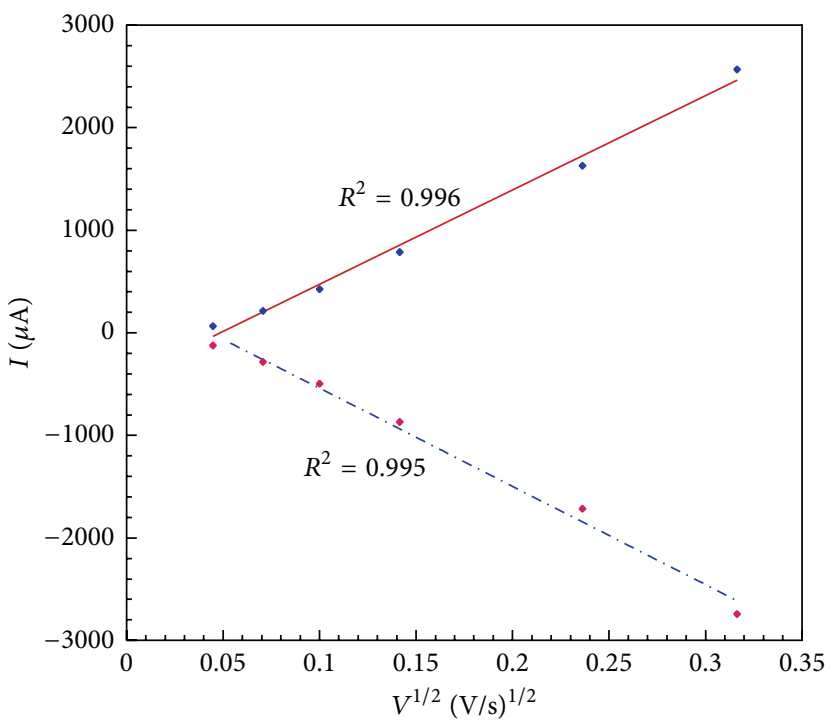

(d)

Figure 2: $\mathrm{CV}$ curves of graphite felt in $0.129 \mathrm{M} \mathrm{KCl}$ at a scan rate of $10 \mathrm{mV} / \mathrm{s}$ and at different scan rates for solutions of (a) $10^{-4} \mathrm{M}$ $\mathrm{Fe}(\mathrm{CN})_{6}{ }^{3-} / \mathrm{Fe}(\mathrm{CN})_{6}{ }^{4-}$, (b) $10^{-4} \mathrm{M} \mathrm{Ru}\left(\mathrm{NH}_{3}\right)_{6}{ }^{3-} / \mathrm{Ru}\left(\mathrm{NH}_{3}\right)_{6}{ }^{4-}$ in $0.129 \mathrm{M} \mathrm{KCl}$ and plots of anodic and cathodic peak currents versus square root of the scan rates $V^{1 / 2}$ in (c) $10^{-4} \mathrm{M} \mathrm{Fe}(\mathrm{CN})_{6}{ }^{3-} / \mathrm{Fe}(\mathrm{CN})_{6}{ }^{4-}$ and (d) $10^{-4} \mathrm{M} \mathrm{Ru}\left(\mathrm{NH}_{3}\right)_{6}{ }^{3-} / \mathrm{Ru}^{-}\left(\mathrm{NH}_{3}\right)_{6}{ }^{4-}$ in $0.129 \mathrm{M} \mathrm{KCl}$.

been presented as it was difficult to immerse the graphite felt in the solution in a repeatable manner because of its hydrophobic character. Figures 2(a) and 2(b) show the CV curves of the graphite felt immersed in a blank $(0.129 \mathrm{M} \mathrm{KCl}$ at a scan rate of $\left.10 \mathrm{mV} \cdot \mathrm{s}^{-1}\right)$ and in a solution of $10^{-4} \mathrm{M}$ $\mathrm{Fe}(\mathrm{CN})_{6}{ }^{3-} / \mathrm{Fe}(\mathrm{CN})_{6}{ }^{4-}$ or $\mathrm{Ru}\left(\mathrm{NH}_{3}\right)_{6}{ }^{3-} / \mathrm{Ru}\left(\mathrm{NH}_{3}\right)_{6}{ }^{4-}$, at different scan rate values (from $2 \mathrm{mV} \mathrm{s}^{-1}$ to $100 \mathrm{mV} \mathrm{s}^{-1}$ ). The specific surface value of the electrode can be estimated from the capacitive current at about $0.12 \pm 0.01 \mathrm{~m}^{2} \mathrm{~g}^{-1}$. This value is close to the geometric surface value $\left(0.15 \mathrm{~m}^{2} \mathrm{~g}^{-1}\right)$, supporting the assumption that alginate does not lower the accessibility of the carbon surface. Note that the electrochemistry at the surface of nonmodified graphite felt has not been performed as carbon is highly hydrophobic. The electrolyte wettability is poor, giving rise to nonreproducible results.

As seen from Figures 2(a) and 2(b), the peak current $\left(I_{\max }\right)$ and the potential difference $(\Delta V)$ between cathodic and anodic peaks increased with increasing scan rate from 2 to $100 \mathrm{mV} \mathrm{s}^{-1}$ for both probes.

$\Delta V$ values of ca. $160 \mathrm{mV}$ at $10 \mathrm{mV} \mathrm{s}^{-1}$ for $\mathrm{Fe}(\mathrm{CN})_{6}{ }^{3-}$ / $\mathrm{Fe}(\mathrm{CN})_{6}{ }^{4-}$ and ca. $180 \mathrm{mV}$ at $100 \mathrm{mV} \mathrm{s}^{-1}$ for $\mathrm{Ru}\left(\mathrm{NH}_{3}\right)_{6}{ }^{3-}$ / $\mathrm{Ru}\left(\mathrm{NH}_{3}\right)_{6}{ }^{4-}$ were larger than theoretical values (ca. $\left.60 \mathrm{mV}\right)$. These results indicate that the redox process is an electrochemically quasi-reversible process $[27,28]$. Figures 2 (c) and $2(\mathrm{~d})$ show that both redox peak currents were linearly proportional to the square root of the scan rate in the range 2 


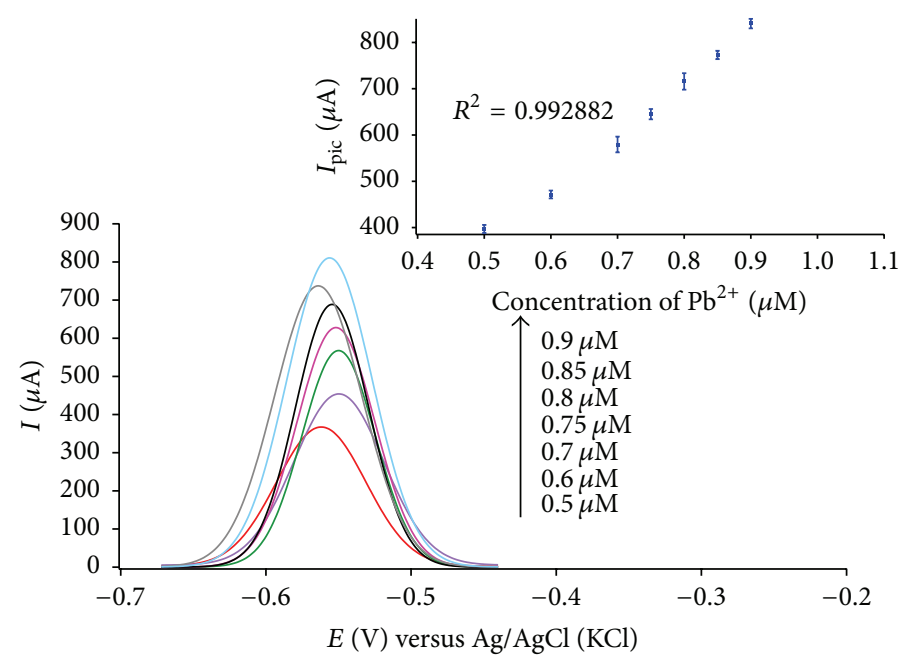

(a)

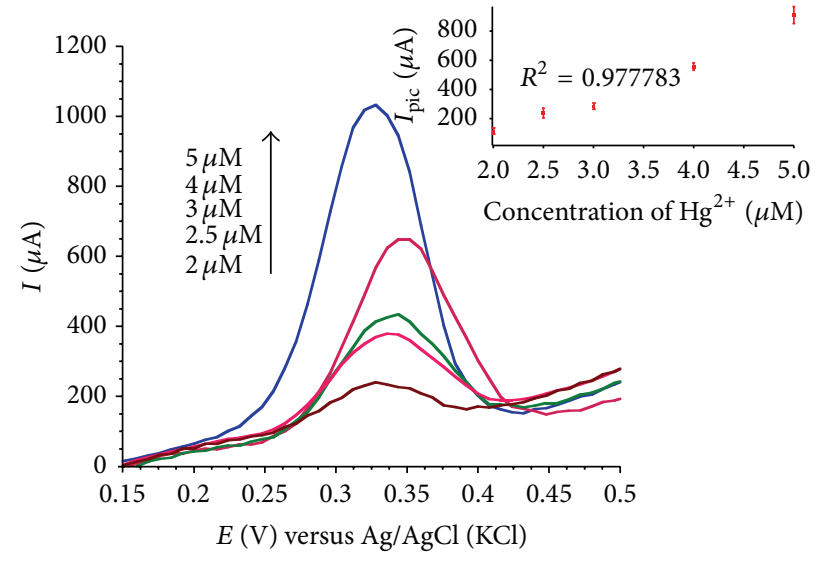

(b)

FIGURE 3: Square wave voltammograms and calibration curves (inset) using graphite felt electrode in $0.1 \mathrm{M}$ sodium acetate/acetic acid buffer at $\mathrm{pH} 4.5$ containing different concentrations of (a) $\mathrm{Pb}^{2+}$ from $0.5 \mu \mathrm{M}$ to $0.9 \mu \mathrm{M}$ and (b) $\mathrm{Hg}^{2+}$ from $2 \mu \mathrm{M}$ to $5 \mu \mathrm{M}$. Note a shift of the baseline due to the capacitive current of the graphite felt.

TABLE 1: Data of the calibration curves.

\begin{tabular}{lcll}
\hline & Regression equations and correlation coefficient $(R)$ & LOD $(\mathrm{M})$ & LOQ $(\mathrm{M})$ \\
\hline $\mathrm{Pb}^{2+}$ & $I_{\text {peak }}=1156.4 C-209.1 ; R=0.993$ & $5.2 \times 10^{-8}$ & $1.5 \times 10^{-7}$ \\
$\mathrm{~Pb}^{2+}($ mix $)$ & $I_{\text {peak }}=5632.6 C-3610.0 ; R=0.971$ & $8.6 \times 10^{-8}$ & $2.6 \times 10^{-7}$ \\
$\mathrm{Hg}^{2+}$ & $I_{\text {peak }}=2485.1 C-422.2 ; R=0.978$ & $2.6 \times 10^{-7}$ & $7.8 \times 10^{-7}$ \\
$\mathrm{Hg}^{2+}($ mix $)$ & $I_{\text {peak }}=750.0 C-2471.4 ; R=0.982$ & $1.1 \times 10^{-7}$ & $3.5 \times 10^{-7}$ \\
\hline
\end{tabular}

$\mathrm{C}: \mathrm{Pb}^{2+}$ and $\mathrm{Hg}^{2+}$ concentration $(\mu \mathrm{M})$.

to $100 \mathrm{mV} \mathrm{s}^{-1}$, with a high value of the correlation coefficient $\left(R^{2} \geq 0.99\right)$. This suggests that the reaction at the electrode corresponds to a diffusion-controlled process [29-33].

Square wave voltammograms obtained for different concentrations of $\mathrm{Pb}^{2+}$ and $\mathrm{Hg}^{2+}$ and the resulting calibration curves are shown in Figure 3. First, the cations $\mathrm{Pb}^{2+}$ and $\mathrm{Hg}^{2+}$ are reduced at the electrode surface (not recorded). Then, the potential is changed going from negative to positive to oxidize the metal previously formed. Well-defined peaks corresponding to $\mathrm{Pb}^{2+}$ and $\mathrm{Hg}^{2+}$ are observed at ca. $-0.55 \mathrm{~V}$ and $+0.33 \mathrm{~V}$ potential, respectively. The peak current increased linearly with increasing metal concentration over the studied concentration ranges $(0.5-1 \mu \mathrm{M}$ for lead and 1$5 \mu \mathrm{M}$ for mercury). There is a shift of the potential as function of the concentration. This behavior has also been observed in the literature [33-35] and is linked to slight modification of the experimental conditions (temperature, geometry of the cell, etc.).

The calculated equations were $I_{\text {peak }}(\mu \mathrm{A})=1156.4 C(\mu \mathrm{M})$ - 209.1 for $\mathrm{Pb}^{2+}$ and $I_{\text {peak }}(\mu \mathrm{A})=2485.1 C(\mu \mathrm{M})-422.2$ for $\mathrm{Hg}^{2+}$, with correlation coefficients $R^{2}$ of 0.993 and 0.978 , respectively. Limit of detection can be obtained by the equation: $\mathrm{LOD}=3.3 \mathrm{Sm}^{-1}$, and limit of quantification by the equation: $\mathrm{LOQ}=10 \mathrm{Sm}^{-1}$, where $S$ is the standard deviation of the intercept and $m$ is the slope of the regression line $[34,35]$. The standard deviation value was evaluated by replicate measurements $(n=4)$. LOD and LOQ values are gathered in Table 1, indicating better performance for lead detection compared to $\mathrm{Hg}^{2+}$. Interestingly, the LOD value for lead $\left(5 \times 10^{-8} \mathrm{M}\right)$ is close to that obtained for ligandmodified felts $\left(2.5 \times 10^{-8} \mathrm{M}\right)[20,21]$. A LOD value of $10^{-9} \mathrm{M}$ for $\mathrm{Pb}^{2+}$ was reported for an unmodified graphite felt but this electrode had a specific surface area of $0.7 \mathrm{~m}^{2} \mathrm{~g}^{-1}$ that is 5 times higher than the one used in this work [19].

The use of graphite felt for the detection of cadmium was finally not adapted because of the loss of the reduction peak of $\mathrm{Cd}^{2+}$ with the repetition of the measurements as it is shown in Figure 4. This phenomenon may be explained by hydrogen bubbles formation due to water reduction as we cycled at very low potentials $(-1.2 \mathrm{~V})$ [19]. Those bubbles are then captured into the void volume of graphite felt and prevent the electronic transfer on the electrode surface.

These results raise the important question of the possible role of the alginate in the process of metal fixation on the electrode surface. As a matter of fact, it has been suggested that carboxylate groups that are present at high density on the alginate backbone are also key binding sites for metals on carbon surfaces [19]. In this context, it is worth emphasizing that the affinity of alginate for the different species used in 


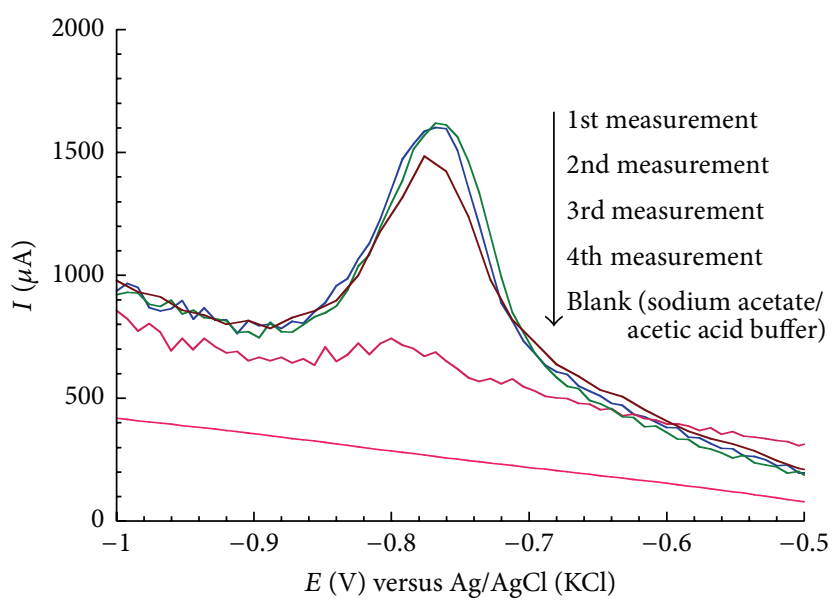

FIGURE 4: Square wave voltammograms using graphite felt electrode in $0.1 \mathrm{M}$ sodium acetate/acetic acid buffer at $\mathrm{pH} 4.5 \mathrm{containing} 6 \times 10^{-8} \mathrm{M}$ of $\mathrm{Cd}^{2+}$. Note that a shift of the baseline related to the capacitive current of the graphite felt.

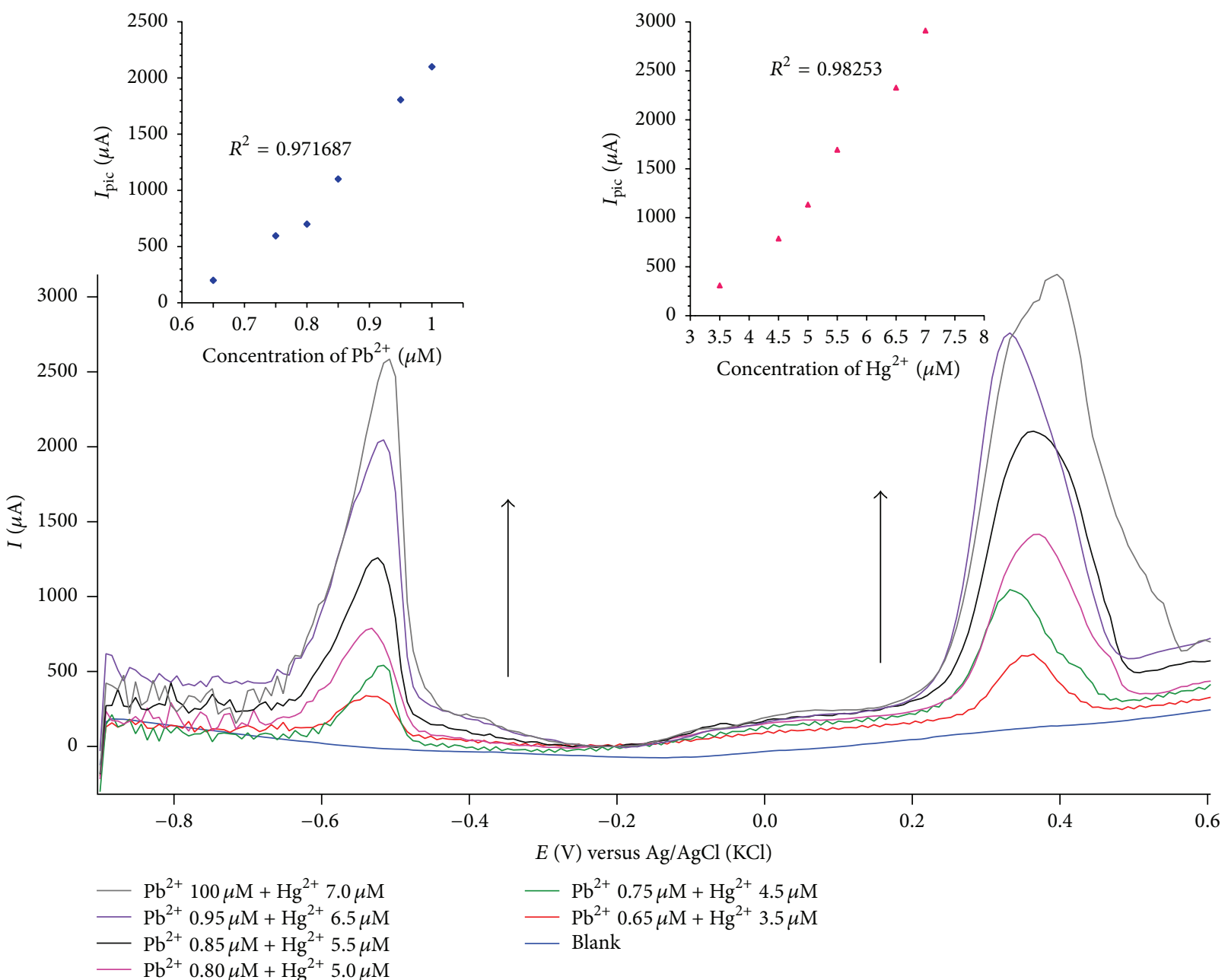

FIGURE 5: Square wave voltammograms and calibrations curve (inset) using graphite felt electrode in $0.1 \mathrm{M}$ sodium acetate/acetic acid buffer at $\mathrm{pH} 4.5$ containing different concentration of $\mathrm{Pb}^{2+}$, from $0.65 \mu \mathrm{M}$ to $1.00 \mu \mathrm{M}$, and $\mathrm{Hg}^{2+}$, from $3.5 \mu \mathrm{M}$ to $7.0 \mu \mathrm{M}$. 
this study is in the order of $\mathrm{Pb}^{2+} \gg \mathrm{Hg}^{2+}>\mathrm{Cd}^{2+}$ [36]. This evolution nicely follows the here-observed trend in metal detection ability of the coated felt, suggesting that the alginate can play an active role in the electrode behavior.

As the detection of $\mathrm{Pb}^{2+}$ and $\mathrm{Hg}^{2+}$ can be achieved at significantly distant potentials (more than $400 \mathrm{mV}$ ), the simultaneous monitoring of the two species by SWV technique was studied. Figure 5 shows the square wave voltammograms obtained for mixtures of $\mathrm{Pb}^{2+}$ (from $6.5 \times 10^{-7}$ to $10^{-6} \mathrm{M}$ ) and $\mathrm{Hg}^{2+}$ (from $3.5 \times 10^{-6}$ to $7 \times 10^{-6} \mathrm{M}$ ) in $0.1 \mathrm{M}$ sodium acetate/acetic acid buffer. Peak current intensity was large enough to detect low amount of $\mathrm{Pb}^{2+}(600 \mu \mathrm{A}$ for $7.5 \times$ $\left.10^{-7} \mathrm{M}\right)$ and $\mathrm{Hg}^{2+}\left(310 \mu \mathrm{A}\right.$ for $\left.3.5 \times 10^{-6} \mathrm{M}\right)$ to be compared with a few tens of $\mu \mathrm{A}$ usually reported for metal detection using SWV [37-39]. LOD and LOQ values obtained from calibration curves (Figure 5) do not differ significantly from those obtained for individual ions (Table 1). Compared to ions detected solely, the intensity of peaks for $\mathrm{Pb}^{2+}$ and $\mathrm{Hg}^{2+}$ differs. This behavior may find various origins including the surface accessibility and the amount of alginic acid trapped in the graphite felt that change the preconcentration of ions and then affect the current density. Accordingly, there are no interferences between the two ions during the simultaneous detection and the binding sites available on the electrode surface are not saturated at the investigated metal concentrations.

Our final target is indeed to use this electrode for real sample analysis. However, it was first important to validate the ability for these hydrophilized felts for metal detection. Going further will require additional studies, especially considering that natural samples often also contain organic substances that can interfere with both the metal ions and the electrode. Our study shows that the as-prepared electrode is easy to handle, of low cost, and ecofriendly. The results achieved are comparable to the ones in the literature involving more sophisticated electrodes (gold wire, carbon nanotubes, etc.). This is due to the high specific surface area. Additionally, the use of alginate is interesting as it can complex not only both $\mathrm{Pb}^{2+}$ and $\mathrm{Hg}^{2+}$ but also other divalent metals. Since the affinity constant of this polymer towards different metals ranges over several orders of magnitudes, it can provide some selectivity on the detection.

\section{Conclusions}

For the first time, it was shown that hydrophilized graphite felt can be used for the electrochemical detection of $\mathrm{Hg}^{2+}$ ions both as single metal species and via its simultaneous detection with $\mathrm{Pb}^{2+}$. This was possible thanks to the structure of the graphite felt (high porosity ( $>95 \%$ ), high surface area, and good electrical conductivity) that allows achieving large peak currents using the SWV method. Our data suggest that the alginate coating also plays a role in the preconcentration of metals at the carbon surface. The described electrode has a low cost and is easy to manipulate and the electrochemical analysis can be performed by simple immersion of the felt in the metal solution. Yet, limit of detection values are still higher than regulatory standards, requiring further improvement of the electrode processing. Evaluation of more complex solutions will also be necessary to further ascertain the potentialities of these materials as environmental sensors.

\section{Conflict of Interests}

The authors declare that there is no conflict of interests regarding the publication of this paper.

\section{References}

[1] S. Caroli, G. Forte, A. L. Iamiceli, and B. Galoppi, "Determination of essential and potentially toxic trace elements in honey by inductively coupled plasma-based techniques," Talanta, vol. 50, no. 2, pp. 327-336, 1999.

[2] A. Malekpour, S. Hajialigol, and M. A. Taher, "Study on solidphase extraction and flame atomic absorption spectrometry for the selective determination of cadmium in water and plant samples with modified clinoptilolite," Journal of Hazardous Materials, vol. 172, no. 1, pp. 229-233, 2009.

[3] W. Zeng, Y. Chen, H. Cui, F. Wu, Y. Zhu, and J. S. Fritz, "Singlecolumn method of ion chromatography for the determination of common cations and some transition metals," Journal of Chromatography A, vol. 1118, no. 1, pp. 68-72, 2006.

[4] J. Li, S. Guo, Y. Zhai, and E. Wang, "High-sensitivity determination of lead and cadmium based on the Nafion-graphene composite film," Analytica Chimica Acta, vol. 649, no. 2, pp. 196201, 2009.

[5] H. Bagheri, A. Afkhami, H. Khoshsafar, M. Rezaei, and A. Shirzadmehr, "Simultaneous electrochemical determination of heavy metals using a triphenylphosphine/MWCNTs composite carbon ionic liquid electrode," Sensors and Actuators, B: Chemical, vol. 186, pp. 451-460, 2013.

[6] K. C. Honeychurch and J. P. Hart, "Screen-printed electrochemical sensors for monitoring metal pollutants," Trends in Analytical Chemistry, vol. 22, no. 7-8, pp. 456-469, 2003.

[7] A. Economou, "Bismuth-film electrodes: recent developments and potentialities for electroanalysis," TrAC-Trends in Analytical Chemistry, vol. 24, no. 4, pp. 334-340, 2005.

[8] C. Liu, Y. Y. Fan, M. Liu, H. T. Cong, H. M. Cheng, and M. S. Dresselhaus, "Hydrogen storage in single-walled carbon nanotubes at room temperature," Science, vol. 286, no. 5442, pp. 1127-1129, 1999.

[9] H. Zhu, J. Wei, K. Wang, and D. Wu, "Applications of carbon materials in photovoltaic solar cells," Solar Energy Materials and Solar Cells, vol. 93, no. 9, pp. 1461-1470, 2009.

[10] S. Xin, Y.-G. Guo, and L.-J. Wan, "Nanocarbon networks for advanced rechargeable lithium batteries," Accounts of Chemical Research, vol. 45, no. 10, pp. 1759-1769, 2012.

[11] L. Bouabdalaoui, L. Legrand, D. Féron, and A. Chaussé, "Improved performance of anode with iron/sulfur-modified graphite in microbial fuel cell," Electrochemistry Communications, vol. 28, pp. 1-4, 2013.

[12] B. Cercado-Quezada, M.-L. Delia, and A. Bergel, "Electrochemical micro-structuring of graphite felt electrodes for accelerated formation of electroactive biofilms on microbial anodes," Electrochemistry Communications, vol. 13, no. 5, pp. 440-443, 2011.

[13] B. Erable, L. Etcheverry, and A. Bergel, "Increased power from a two-chamber microbial fuel cell with a low-pH air-cathode compartment," Electrochemistry Communications, vol. 11, no. 3, pp. 619-622, 2009. 
[14] G. Aragay and A. Merkoçi, "Nanomaterials application in electrochemical detection of heavy metals," Electrochimica Acta, vol. 84, pp. 49-61, 2012.

[15] V. K. Gupta, M. L. Yola, N. Atar, Z. Ustundağ, and A. O. Solak, "A novel sensitive $\mathrm{Cu}(\mathrm{II})$ and $\mathrm{Cd}(\mathrm{II})$ nanosensor platform: graphene oxide terminated $\mathrm{p}$-aminophenyl modified glassy carbon surface," Electrochimica Acta, vol. 112, pp. 541-548, 2013.

[16] J. Morton, N. Havens, A. Mugweru, and A. K. Wanekaya, "Detection of trace heavy metal ions using carbon nanotubemodified electrodes," Electroanalysis, vol. 21, no. 14, pp. 15971603, 2009.

[17] Y. Oztekin, A. Ramanaviciene, N. Ryskevic et al., "1,10-Phenanthroline modified glassy carbon electrode for voltammetric determination of cadmium(II) ions," Sensors and Actuators B: Chemical, vol. 157, no. 1, pp. 146-153, 2011.

[18] B. Feier, D. Floner, C. Cristea, E. Bodoki, R. Sandulescu, and F. Geneste, "Flow electrochemical analyses of zinc by stripping voltammetry on graphite felt electrode," Talanta, vol. 98, pp. 152-156, 2012.

[19] R. Nasraoui, D. Floner, and F. Geneste, "Analytical performances of a flow electrochemical sensor for preconcentration and stripping voltammetry of metal ions," Journal of Electroanalytical Chemistry, vol. 629, no. 1-2, pp. 30-34, 2009.

[20] R. Nasraoui, D. Floner, and F. Geneste, "Improvement in performance of a flow electrochemical sensor by using carbamoylarms polyazamacrocycle for the preconcentration of lead ions onto the electrode," Electrochemistry Communications, vol. 12, no. 1, pp. 98-100, 2010.

[21] R. Nasraoui, D. Floner, C. Paul-Roth, and F. Geneste, "Flow electroanalytical system based on cyclam-modified graphite felt electrodes for lead detection," Journal of Electroanalytical Chemistry, vol. 638, no. 1, pp. 9-14, 2010.

[22] B. Feier, D. Floner, C. Cristea, R. Sandulescu, and F. Geneste, "Development of a novel flow sensor for copper trace analysis by electrochemical reduction of 4-methoxybenzene diazonium salt," Electrochemistry Communications, vol. 31, pp. 13-15, 2013.

[23] B. Le Ouay, T. Coradin, and C. Laberty-Robert, "Silica-carbon hydrogels as cytocompatible bioelectrodes," Journal of Materials Chemistry B, vol. 1, no. 5, pp. 606-609, 2013.

[24] B. Le Ouay, T. Coradin, and C. Laberty-Robert, "Mass transport properties of silicified graphite felt electrodes," The Journal of Physical Chemistry C, vol. 117, no. 31, pp. 15918-15923, 2013.

[25] D. Martín-Yerga, M. B. González-García, and A. Costa-García, "Electrochemical determination of mercury: a review," Talanta, vol. 116, pp. 1091-1104, 2013.

[26] J. Li, S. Guo, Y. Zhai, and E. Wang, "A graphene-based electrochemical sensor for rapid determination of phenols in water," Analytica Chimica Acta, vol. 649, pp. 196-201, 2009.

[27] O. J. Yoon, C. H. Kim, I.-Y. Sohn, and N.-E. Lee, “Toxicity analysis of graphene nanoflakes by cell-based electrochemical sensing using an electrode modified with nanocomposite of graphene and Nafion," Sensors and Actuators B: Chemical, vol. 188, pp. 454-461, 2013.

[28] M. Mazloum-Ardakani, H. Rajabi, and H. Bietollahi, "Electrocatalytic oxidation of Cysteine by indigo carmine modified glassy carbon electrode," Journal of the Argentine Chemical Society, vol. 97, no. 2, pp. 106-115, 2009.

[29] S. Yang, D. Guo, L. Su et al., "A facile method for preparation of graphene film electrodes with tailor-made dimensions with Vaseline as the insulating binder," Electrochemistry Communications, vol. 11, no. 10, pp. 1912-1915, 2009.
[30] W.-J. Lin, C.-S. Liao, J.-H. Jhang, and Y.-C. Tsai, “Graphene modified basal and edge plane pyrolytic graphite electrodes for electrocatalytic oxidation of hydrogen peroxide and $\beta$ nicotinamide adenine dinucleotide," Electrochemistry Communications, vol. 11, no. 11, pp. 2153-2156, 2009.

[31] H. Yin, Q. Ma, Y. Zhou, S. Ai, and L. Zhu, "Electrochemical behavior and voltammetric determination of 4-aminophenol based on graphene-chitosan composite film modified glassy carbon electrode," Electrochimica Acta, vol. 55, no. 23, pp. 71027108, 2010.

[32] L. Tang, Y. Wang, Y. Li, H. Feng, J. Lu, and J. Li, "Preparation, structure, and electrochemical properties of reduced graphene sheet films," Advanced Functional Materials, vol. 19, no. 17, pp. 2782-2789, 2009.

[33] H. Chen, Y. Wang, Y. Liu, Y. Wang, L. Qi, and S. Dong, "Direct electrochemistry and electrocatalysis of horseradish peroxidase immobilized in Nafion-RTIL composite film," Electrochemistry Communications, vol. 9, no. 3, pp. 469-474, 2007.

[34] M. L. Yola, N. Atar, M. S. Qureshi, Z. Üstündag, and A. O. Solak, "Electrochemically grafted etodolac film on glassy carbon for $\mathrm{Pb}(\mathrm{II})$ determination," Sensors and Actuators B: Chemical, vol. 171-172, pp. 1207-1215, 2012.

[35] "Validation of analytical procedures: ICH harmonised tripartite guideline," in Proceedings of the International Conference on Harmonisationof Technical Requirements for Registration of Pharmacueticals for Human Use, 2005.

[36] G. Bayramoğlu, I. Tuzun, G. Celik, M. Yilmaz, and M. Y. Arica, "Biosorption of mercury(II), cadmium(II) and lead(II) ions from aqueous system by microalgae Chlamydomonas reinhardtii immobilized in alginate beads," International Journal of Mineral Processing, vol. 81, no. 1, pp. 35-43, 2006.

[37] D. Li, J. Jia, and J. Wang, "Simultaneous determination of Cd(II) and $\mathrm{Pb}(\mathrm{II})$ by differential pulse anodic stripping voltammetry based on graphite nanofibers-Nafion composite modified bismuth film electrode," Talanta, vol. 83, no. 2, pp. 332-336, 2010.

[38] I. Palchetti, S. Laschi, and M. Mascini, "Miniaturised strippingbased carbon modified sensor for in field analysis of heavy metals," Analytica Chimica Acta, vol. 530, no. 1, pp. 61-67, 2005.

[39] R.-X. Xu, X.-Y. Yu, C. Gao et al., "Non-conductive nanomaterial enhanced electrochemical response in stripping voltammetry: the use of nanostructured magnesium silicate hollow spheres for heavy metal ions detection," Analytica Chimica Acta, vol. 790, pp. 31-38, 2013. 

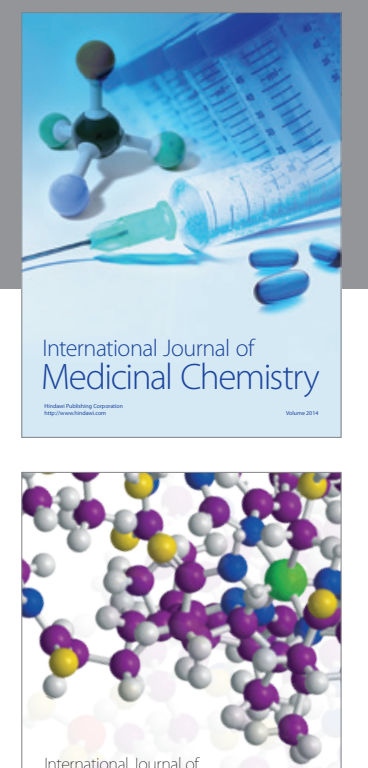

\section{Carbohydrate} Chemistry

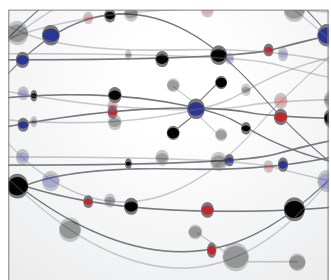

The Scientific World Journal
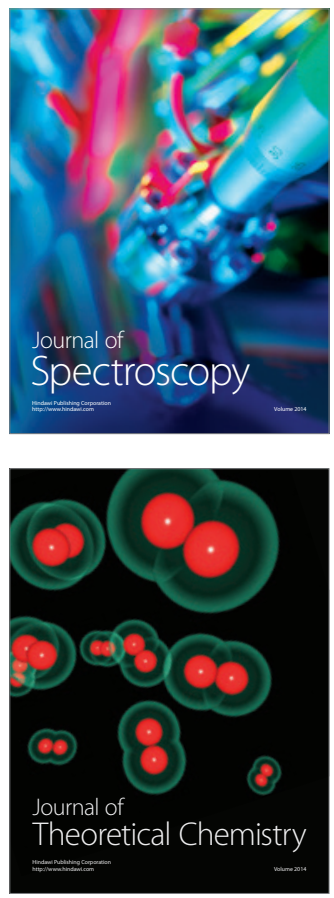
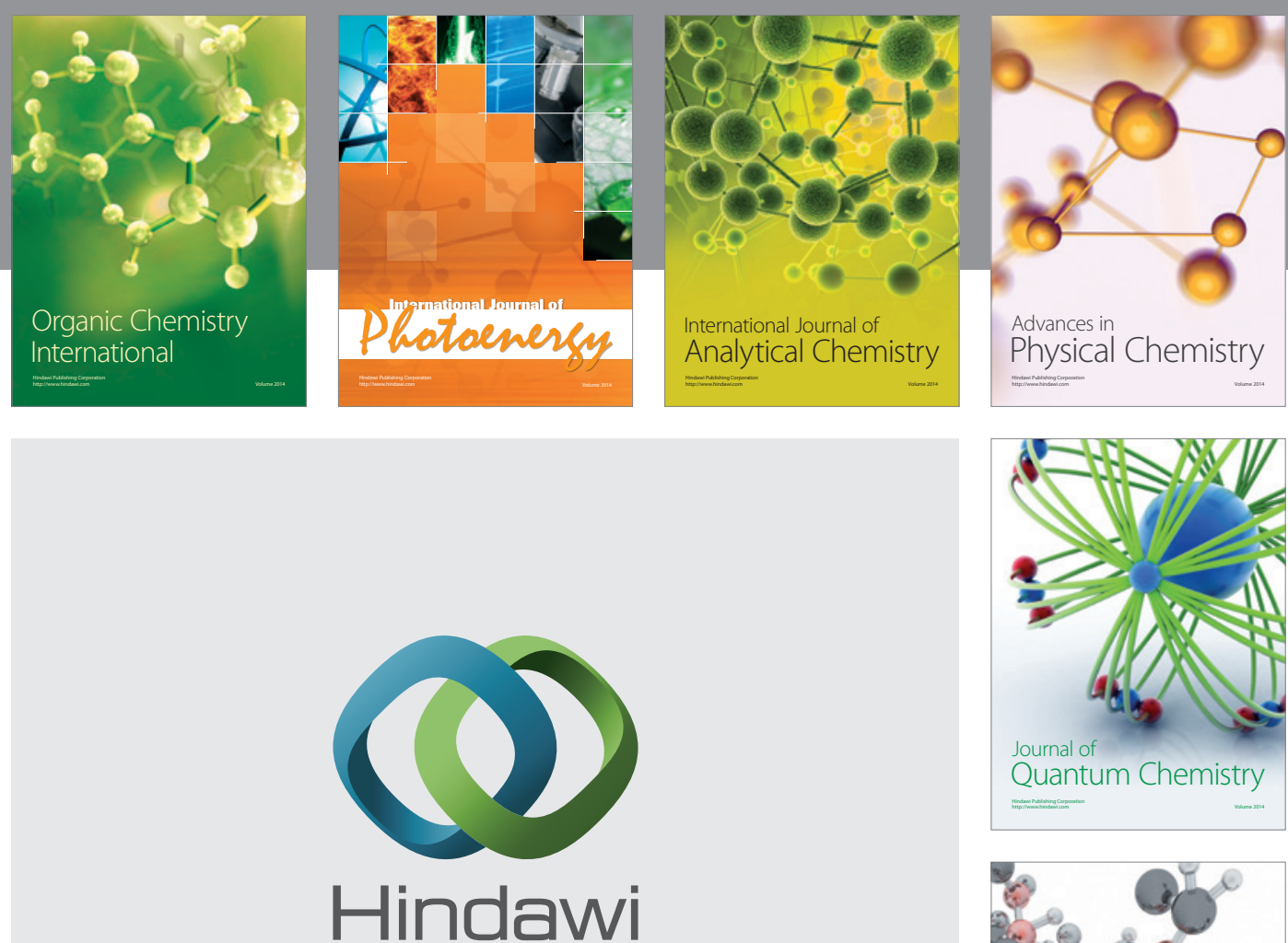

Submit your manuscripts at

http://www.hindawi.com

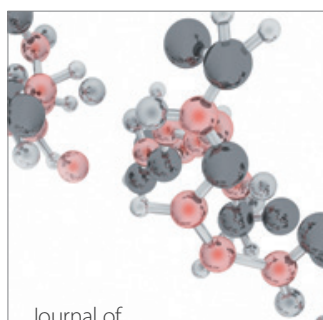

Analytical Methods

in Chemistry

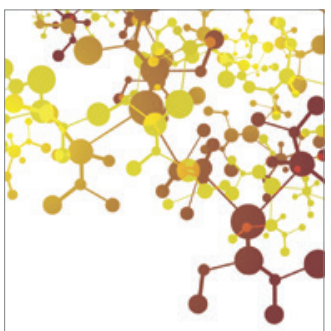

Journal of

Applied Chemistry

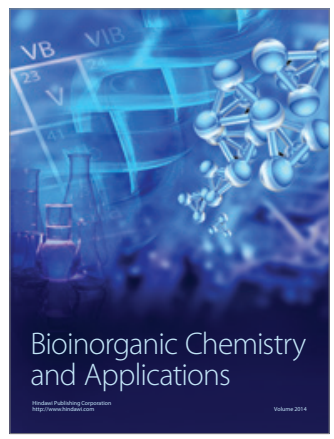

Inorganic Chemistry
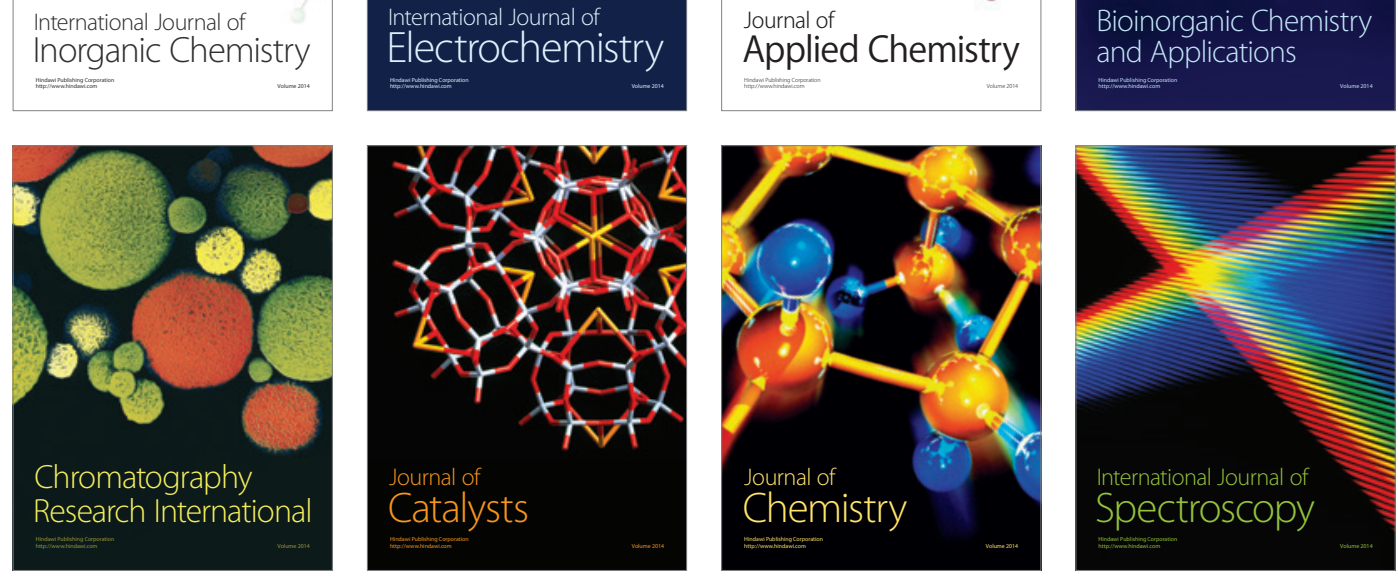